\title{
THE ORGANIZED CRIME IN WESTERN BALKANS IN THE AGE \\ OF GLOBALIZATION- TRAFFICKING IN NARCOTICS AND \\ MONEY LAUNDRY
}

Fidan HALITI, PhD. C. (iD

University of Prishtina, Faculty of Philosophy,Department of History, fidan.haliti@hotmail.com

\author{
Article history: \\ Submission 25 March 2020 \\ Revision 10 May 2020 \\ Accepted 05 Julu 2021 \\ Available online 31 August 2021
}

\section{Keywords:}

Western Balkans,

Globalization,

Organized Crime,

Narcotics,

Money Laundry.

DOI:

https://doi.org/10.32936/pssj.v5i2.228

\begin{abstract}
A b s t r a t
This research addresses the activity of transnational organized crime in the Westerns Balkans region, particularly the activity of trafficking in narcotics and money laundry. This problematic phenomenon is treated on the aspect of newly created circumstances in the age of globalization, where the entire world is facing the transformation in the political and economic aspect developments that are impacting the field of security as well.

In this period, these countries faced institutional fragility, lack of proper capacities in fight against new forms of organized criminality, lack of inter-state cooperation etc. this situation was used as an opportunity by the criminal organizations with their reach in the entire region, creating the so called Balkan Road which is used for trafficking of narcotics towards Western Europe countries. In this research is expressed the amount of narcotics trafficked and illicit profits from this activity, divided by regional countries for the period 2009-2012. This paper argues how transnational organized crime by exploiting the globalization era facilities has adapted to these newly created circumstances and is increasingly exceeding the capabilities of the countries of a traditional organizations and forms of security in responding appropriately. The interstate cooperation aspect and the use of an interactive approach at technical and operational levels is increasingly being considered as a tangible opportunity to deal with this phenomenon.

The paper draws conclusions on how the organized crime threats have had influence on security approaches in the Western Balkans as well as pushing the countries towards an inter-state approach in addressing these threats. Security field contemporary literature as well as reports and assessments of various security agencies have been used in drawing research results.
\end{abstract}

\section{Introduction}

This paper addresses challenges posed by transnational organized crime in globalization era to the issue of security for the Western Balkan countries and the impact of narcotics trafficking through Balkan routes on the security of European countries. Considering the changes occurring in the era of globalization, such as technology, telecommunications, economic liberalization and political transitions, the organized crime used the opportunities coming from these circumstances to expand its network and change the ways of operating and organizing.
Nowadays, the organized crime is of a global reach, establishing the features of a transnational cooperation and criminal organizations are increasingly changing the forms of their organization, disregarding the ethnic element which was characteristic of criminal organizations in the past. By using illegally created assets, organized crime is threatening different countries and from this situation, in the international aspect, the state as alone is increasingly being seen as an insufficient actor to face this global threat.

These challenges arising in the age of globalization in the field of security require global approach to properly address them, that's 
why we are increasingly hearing expressions such as global approach, politics or global governance in the field of security. The threats in the field of security posed by organized crime in the globalization era for the countries of the Western Balkans are main focus of this paper, specifically addressing the activity of drug trafficking and money laundering in these countries. As a result of such work, important conclusions have been drawn on the amount of narcotics trafficking, the illegal profits of criminal groups in these countries gained from the trafficking of narcotics through the Balkan trafficking routes. The research therefore draws conclusions regarding the presence, extent, organization and operation of organized crime in the Western Balkans. In addition to this, there are presented the threats posed by organized crime in the processes of democratic transition and integration to the societies of these countries. Conclusions are also given related to contemporary approach on combating transnational organized crime and the impact that this phenomenon has on changing the security approaches.

In compliance with the goals and objectives of the research subject I made the following research questions associated with the hypothesis:

The research question

- How much and in what way are the threats from transnational organized crime impacting the change in security approaches as well as on establishing of an interactive strategy between states?

How is the organized crime endangering the security and functioning of the rule of law in the Western Balkan countries through drug trafficking and other criminal activities?

Hypothesis

Posed threats in the security field by the organized crime are exceeding the capabilities of the states to face this phenomenon alone, it is increasingly deemed necessary drafting new strategies that will focus on cooperation and interaction between states.

The organized crime in the Western Balkans is threatening the security and functioning of the rule of law in these countries and the criminal organizations in these countries have turned the Balkans into a route of drug trafficking towards European Union countries.

The methodology used in this research is based on various instruments such as analysis of the literature of various authors dealing with issues of security and organized crime, analysis of government documents, activities and policies, research of international assessment documents, analysis of reports of various organizations.
In order to achieve the results on the amount of narcotics trafficked and the amount of illegal profits from this activity for the countries of the Western Balkans, reports and assessments of Europol, Interpol, the United Nations Office on Drugs and Crime, as well as various governmental and non-governmental organizations were used.

Structurally this paper consists of five sections. The first section is about an introduction providing data on the importance of the topic, as well as the methodology used to achieve the research results.

The second section analyzes the impact of globalization processes in relation to security issues, the challenges arising in the field of security by transnational criminal organizations in this period and the indispensable need to change the security approaches in facing new forms of threats in this period.

The theoretical and conceptual views as well as legal definitions on transnational organized crime are provided in the third section of this paper. The fourth section discusses the activity of organized crime in the countries of the Western Balkans, where important data are presented on the extent, forms of organization of organized crime in the Western Balkans countries and the Balkan trafficking routes. In addition to this, the statistics on the amount of narcotics trafficking and the illegal benefits of this trafficking are provided for each Western Balkan country for the period 2009-2012. The fifth section presents the conclusions, as well as the sources used.

\section{Globalization and Challenges in the field of} Security due to the Transnational Organized Crime

The globalization is a process of international integration that includes economic, cultural issues, exchange of ideas, goods and services, etc. Particularly great technological development has a primary impact on the globalization of contemporary societies, which also has an impact on increasing interdependence between societies and states. (Berisha, 2008).

According to Francis Fukuyama, "the phenomenon we label today as globalism is only the latest repetition of a process that has evolved continuously over the past few centuries with the spread of technologies related to transportation, communications and information" (Fukuyama, 2012).

Globalization as a process first of all includes economic processes, international trade, international finance, which is accompanied by increased economic and trade cooperation, 
which processes then affect cultural issues and other areas, including the field of security.

In economic terms, globalization is also characterized by the development of global financial systems, the transfer of capital from one country to another, a process that has an impact on the creation and functioning of multinational corporations (Fukuyama, 2012).

The processes of globalization today affect all societies and all individuals. Global problems or issues are so numerous that it is impossible for them to be addressed by states individually and by this the traditional role of states is increasingly fading. This shows the need for other organizational levels with a transnational character to address the issues and problems faced by society in the era of globalization (Berisha, 2008).

Reduction of the power of the state as well as the determination of how to use left power is a result of globalization is. This transformation is expressed by the selection of new and combined ways of governing, which aims to include many formal and informal actors within the state itself as well as the coordination with state and non-state actors in the international arena such as various international organizations, non-governmental organizations etc (Mingst, 2008).

In addition to the positive aspects, globalization has brought many various nature problems that nowadays require addressing, among them, organized crime which is increasingly taking on the characteristics of transnational organization.

The liberalization of market and removal of border barriers that occurred in the age of globalization were also used for various criminal activities, such as illegal human trafficking, drug trafficking, prostitution, trademark counterfeiting, economic crime, money laundering etc (Alan Collins, 2014).

Nowadays, transnational organized crime activities have reached alarming levels, spreading almost all over the globe, with greater concentration in certain parts of the globe especially in those regions where processes of change of political systems are taking place, in countries and regions where various crises of a political or economic nature are taking place. New developments in this period will increasingly expose states and societies to the consequences of transnational organized crime, endangering national security, society and the rule of law. The forms in which the organized crime is manifested today, it will be very difficult for states to deal with this phenomenon only with limited state tools or strategies, to make sure for the proper addressing of this phenomenon, there will be an ever-increasing need for cooperation of state and non-state bodies at the international level (Collins, 2014).

Traditional security theories or concepts that were mainly based on issues of war and peace with state as a key actor will increasingly be insufficient to successfully fight organized crime (Collins, 2014).

In response to disturbing trends in the spread and organization of organized crime, states and international organizations began to develop almost unified and flexible strategies focusing on the international cooperation of various actors, including non-state actors. Thus, in 1996, the United States of America, in the national strategy for the fight against organized crime, envisaged the most intensive international involvement and cooperation to address the threats posed by organized crime. After that, the European Union, feeling the danger from the spread and organization of organized crime, manifested in EU countries originating from the countries of the Soviet Union, Eastern Europe and the Balkans, responded by drafting strategies against organized crime and the focus of these strategies was foreseen strengthened regional cooperation.

To successfully deal with the threats of organized crime, the European Union established the European Police Office (EUROPOL) in 1994, that reached full operational status in 1999. International financial institutions, which were also the main promoters of market liberalization and globalization as a whole, based on the new threats in the field of finance that came as a result of globalization, new strategies began to develop to cope with the rise of financial crime. The United Nations began unifying legislative aspects against transnational organized crime by signing the United Nations Convention against Transnational Organized Crime, and then the Anti-Corruption Convention in 2005 (Collins, 2014).

\section{Understanding the Organized Crime and} Transnational Criminal Organizations

The organized crime as a concept and activity is an illegal activity with typologies of criminal phenomena related to the exercise of criminal organizations. As an activity it extends to different social and economic aspects, while in terms of geographical reach, especially in the era of globalization it has a global expansion. The activities of the organized crime are carried out by professional organized criminal groups, having strict defined hierarchy, discipline and norms of behavior. These organized groups carry out various illegal activities, with the primary purpose of material benefit, cooperating with government representatives at the local, state level and with various non-state actors as well. One of the characteristics of organized crime is the 
close connection in business relations with representatives from the government, financial institutions, economic companies and political parties (Suçeska, 2006).

Its strength derives from its ability to adapt very flexibly to changes in the conditions in which it operates and to all the repressive measures taken by organized society against it. In fact, the organized crime is a well-organized criminal organization, having its hierarchy, discipline, responsibility, loyalty and clear division of duties. The aim of these criminal groups is the greatest possible benefits and legalizing the accumulated gain. (Suçeska, 2006).

The key objective of the organized crime carriers are social institutions and legalizing the assets gained illegally, precisely through these institutions.

Organized crime, especially from the 1990s onwards, where many political and economic transformations took place almost all over the globe, appears as a problem for the entire International Community. Multinational organized crime means the joint criminal groups of individual states, in such a way that their activity takes place in the largest number of states" (Korajlic and Muharremi 2009)

"Organized crime occurs as a system parallel to the state system and can be defined as a social structure which criminally operates outside the control of the public (opinion) and the government" (Petroviq and Dobovshek, 2007)

Based on some Interpol assessments, organized criminal groups, by taking advantage of the fragility of the political and security system in the countries of Eastern Europe that once were under the Soviet Union influence, have managed to spread such influence in these regions by establishing very powerful networks having state features within the state itself (Korajlic and Muharremi 2009)

Their organizational structure consists of groups of people belonging to various countries, different ethnicities, no longer united by the same origin, but only by a common interest and operating simultaneously in more than one country. Such organized groups with international networks, operate in a very wide area, from the Balkan countries and extending throughout Central and Eastern Europe, Russia, Latin America, Asian and African countries. Illegal trafficking run by these criminal organizations are drugs, weapons, human trafficking, clandestine, stolen cars, money laundering, strategic goods, such as energy resources and others. According to Europol estimates, from the cooperation of criminal organizations of a transnational character,
250 tons of cocaine are transported every year from South American countries by sea or air, and the main points of arrival are found in Western Europe (Spain, Netherlands, Italy, Britain and Greater Europe), as well as in Central and Eastern Europe and the Balkan countries, to be distributed in the countries of the European Union (Sciacchitano, 2007).

Considering the complexity of organized crime manifested in contemporary society and the growing tendency for the global reach, the United Nations Organization began designing strategies and efforts to define transnational organized crime in order to achieve a unique definition for all countries. The first attempt in this direction is the United Nations Convention against Transnational Organized Crime (UNTOC), which was adopted in September 2003.

\section{The Activity of the Organized Crime in} Western Balkans Countries as a Challenge for the Security, Trafficking with Narcotics and Money Laundry

After the 90 s period, a time when great changes took place globally, such as the fall of the Iron Curtain which is considered the end of the Cold War, an event that gave hope to all mankind and in these new circumstances were created the conditions for a good cooperation in all segments of social life. It is exactly this period in which countries of the Western Balkans was quite challenging and problematic. The main concern of the region in this period was mainly related to state building (Doninovska, 2013).

The countries of the Western Balkans, Albania, Montenegro, Kosovo, Macedonia, Serbia, Bosnia and Herzegovina and Croatia, have gone through a serious situation after the 1990s. Albania faced anarchy for longer period of time dominating the Albanian political scene and a difficult democratic transition, then the violent dissolution of Yugoslavia proved that the democratic transition in these areas would be very costly and great commitment would be required in this part of Europe (Paszkiewicz, 2013).

The Western Balkans has so far remained the continent's least integrated and most volatile region. Even after overcoming open conflicts and beginning the process of democratic transition, these countries faced a lack of consensus on reforms, limited democratic experience and weak institutions that hindered political and economic progress. The delayed and unimplemented reform program shifted countries from the path of a fully functioning market economy to low economic performance, 
declining living standards, rising unemployment rate and poverty (Paszkiewicz, 2013).

Due to the specifics and events that the countries of the Western Balkans went through, these also affected the plan of governance in general, this was reflected especially in the field of security. These countries faced institutional fragility, lack of adequate capacities to fight new forms of organized crime, lack of interstate cooperation in combating crime, etc. This situation was used quite well by criminal organizations which spread their network throughout the region, creating the so-called "Balkan Road", which was initially used for trafficking narcotics and human beings mainly having Western Europe as a destination (Report on the situation of the Organized Crime and Economic Crime in the Southeast Europe 2005, Regional Project Carpo, European Commission).

The experience has shown that crime in various forms tends to penetrate first of all in countries with democracies and institutions that are in the process of consolidation as well as in the countries with developed economies. In these countries there is a suitable environment for the development and spread of various criminal acts. In this very same situation are the countries of the Western Balkans since 90 s until today and they are still in a phase of democratic transition having unstable economy, weak rule of law, etc.

The Balkan route of trafficking with narcotics as well as other organized criminal activities, serves as a transit route between drug producing countries to one of the largest drug consuming markets, such as Western Europe. Various types of drugs are smuggled through this route such as heroin, cocaine, cannabis products, amphetamines.

Heroin, mostly produced in countries like Afghanistan, Pakistan and Iran. According to the 2005 World Drug Report, about 410 metric tons of heroin were produced in Afghanistan and most of it was transported to Europe and Russia via Balkan routes (UNDOC World Report on Drugs, 2006).

Regarding the trafficking of narcotic substance heroin, it is trafficked from the countries of production in Asia largely by Turkish criminal groups cooperating with Albanian groups that smuggle this substance in Europe through Italy.

Another route for heroin trafficking to Western and Central Europe is the Turkey-Bulgaria-Romania-Hungary route (International Narcotics Control Board, Report of the International Narcotics Control Board for 2013, Vienna International Centre).
The confiscated heroin and opium from the customs authorities in Western Europe and Central one from the year 2011 is 1.4 tons and 3.3 tons in 2012 (International Narcotics Control Board, Report of the International Narcotics Control Board for Vienna International Centre, 2013).

The Balkan countries, despite becoming a transit country for various drug trafficking to European countries, at the same time a significant amount of narcotics is sold in these there as well and this is stated in the report of the United Nations Office on drugs and crime as well.

According to the United Nations Office on Drugs and Crime, The drug type heroin expressed in $\mathrm{kg}$, consumed in the Western Balkans countries for the period of 2009-2012, it is as follows:

- Albania, lower estimate 331, medium estimate 416, higher estimate 511;

- Bosnia and Hercegovina, lower estimate 285, medium estimate 358 higher estimate 439;

- Croatia , lower estimate 362, medium estimate 455, higher estimate 559;

- Kosova, lower estimate 164, medium estimate 206, higher estimate 253;

- North Macedonia, lower estimate 255, medium estimate 321, higher estimate 394;

- Monte Negro, lower estimate 53, medium estimate 66, higher estimate 82 ;

- Serbia, lower estimate 485, medium estimate 609, higher estimate 748

(United Nations Office on Drugs and Crime Vienna, 2015).

From trafficking narcotics, Western Balkans countries criminal groups manage to secure large material benefits which then, through various economic processes and transactions, they introduce them into normal economic flows, thus committing money laundering. The assessment that emerges from the report of the United Nations Office results in these benefiting figures for the countries of the Western Balkans and these benefits are estimated only from the trafficking of heroin and opium. The total of benefits from trafficking of heroin and opium per country for the period of 2009-2012 expressed in million/American dollars:

- Albania, lower estimate 255, medium estimate 320, higher estimate 392;

- Bosnia and Hercegovina, lower estimate 32, medium estimate 40, higher estimate 49;

- Croatia , lower estimate 177, medium estimate 223 , higher estimate 273 ; 
- Kosova, lower estimate 20, medium estimate 25, higher estimate 31 ;

- North Macedonia, lower estimate 31, medium estimate 39 , higher estimate 47 ;

- $\quad$ Monte Negro, lower estimate 9, medium estimate 11, higher estimate 14 ;

Serbia, lower estimate 27 , medium estimate 33 , higher estimate 41. (Drug Money the illicit proceeds of opiates trafficked on the Balkan route, 2015 United Nations Office on Drugs and Crime). Cocaine, vastly produced in in Latin America countries. (Drug use and its consequences in the Western Balkans, 2006, European Monitoring Centre for Drugs and Drug Addiction).

Global production of cocaine in year 2005 is estimated to be 910 metric tons (Drug use and its consequences in the Western Balkans, 2006, European Monitoring Centre for Drugs and Drug Addiction).

The quantity of this drug from the producing countries has two main destinations, one for the South American market and the other for Western and Central Europe.

In Europe, cocaine is trafficked through two routes: one across the Atlantic Ocean to the Netherlands and Spain and the other across the Adriatic Sea to Greece, Albania, Montenegro and Croatia (Drug use and its consequences in the Western Balkans, 2006, European Monitoring Centre for Drugs and Drug Addiction).

Another route of cocaine trafficking passing through the Balkan countries is the Black Sea route that goes through Bulgaria, Romania, Hungary, with the main destination being Western Europe (Report of the International Narcotics Control Board for 2013, International Narcotics Control Board).

The confiscated amount of cocaine for 2006 in Western Europe and Central one is 120 tons, while in 2008 is 60 tons, in 201134.2 tons and in year 2012 is 35.9 tons (Report of the International Narcotics Control Board for 2013, International Narcotics Control Board). A great amount of this quantity went through Balkan trafficking routes.

Cannabis products, mainly consisting of three different products: herbal cannabis (marijuana), hashish and cannabis oil, are also trafficked via the Balkan route and except being trafficked to Western Europe, this type of drug has a high consumption in Balkan countries as well which in fact produce it as well. The amount of global cannabis production is estimated to be 45,000 metric tons per year (Report on the situation of the
Organized Crime and Economic Crime in the Southeast Europe 2005, Regional Project Carpo, European Commission).

The countries with the highest level of cultivation are Morocco, followed by Afghanistan and Pakistan. European countries of its cultivation are considered to be the Netherlands and Albania (Report on the situation of the Organized Crime and Economic Crime in the Southeast Europe 2005, Regional Project Carpo, European Commission). The greatest consumption market of this drug Europe and that's why the main artery or trafficking is the Balkan path towards Europe.

Marihuana is trafficked mainly through sea, using the ports of Italy, Albania, Croatia, and Montenegro not excluding other methods of trafficking. This type of drug has great consumption in the Western Balkans countries as well delivered mainly through Albania and Montenegro, Serbia, Bosna and Hercegovina, while Albania is present in the European market mainly through two routes, through Italy and Greece (Report on the situation of the Organized Crime and Economic Crime in the Southeast Europe 2007, Regional Project Carpo, European Commission).

Amphetamine type stimulators, at the global level main producers of this type drugs are considered to be China followed by Philippines then Poland. The production on the global level is considered to be 480 metric tons. (Report on the situation of the Organized Crime and Economic Crime in the Southeast Europe 2007, Regional Project Carpo, European Commission). This type of drugs based on the evaluations is produced in other Central and Western Europe countries as well and as for the Balkan countries, the reports on the level of consumers or smugglers, are in lower numbers. Among the Balkan countries, Serbia is considered as the most important market of these synthetic drugs (Report on the situation of the Organized Crime and Economic Crime in the Southeast Europe 2005, Regional Project Carpo, European Commission).

According to two researches related to Balkans, there are two transit roads or narcotic trafficking in Balkans, the western road going through Albania towards Italy the northern road going through Balkan countries toward Austria. The annual amounts of trafficking with narcotics through Balkan roads is estimated to be about 20 milliard dollars (Drug use and its consequences in the Western Balkans 2006 European Monitoring Centre for Drugs and Drug Addiction).

Considering the fact that in Europe the number of persons having experience with use of drugs is considered to be about 40 million people and this evaluation is for the year 2006 (Report on the 
situation of the Organized Crime and Economic Crime in the Southeast Europe 2007, Regional Project Carpo, European Commission). This makes the European narcotics market very lucrative for criminal organizations from the Western Balkan countries. Such groups make good use of the geographical position of these countries, which serve as a connecting bridge of trafficking from Asia to Europe, through criminal groups of Turkey.

The activity of organized crime in the countries of the Western Balkans is quite evident in the economic crime and money laundering. In fact, there is a great and almost inseparable link between organized crime and economic crime and money laundering, because the main purpose of organized crime is to increase profitability and then integrate this profit, i.e. money into the normal flow of economic transactions.

As defined in the "International Convention", money laundry means the possession, benefit, exchange, transfer or use of the wealth created by criminal activity (United Nations Convention against illegal trafficking narcotics and psychotropic substances 1988 , the assembly of the united nations).

During the money laundering process, organized crime exponents take a number of other illegal actions, setting up fraudulent enterprises, various investments in privatization processes and other economic aspects. In the countries of the Western Balkans it is considered that there is a very suitable ground for money laundering where criminal organizations do money laundering in various economic sectors such as: banking and financial sectors, tax evasion, customs fraud, fraud in bankruptcy proceedings etc (Report on the situation of the Organized Crime and Economic Crime in the Southeast Europe 2007, Regional Project Carpo, European Commission).

To combat money laundering phenomenon, the countries of the Western Balkans have signed the international and European conventions related to the prevention of money laundering, and financial intelligence units have been set up as obligations under international conventions on money laundering. Regarding the signing of these conventions Kosovo is the only country that differs, which is not yet a member of the United Nations, but with its "Constitution" she takes responsibility for their implementation (Assembly of the Republic of Kosovo, 2008).

\section{Conclusions}

The international relations system and the international security system have undergone great changes in the period of globalization. This process of change of a great dynamic was enabled by technological development and the process of globalization. In this relatively short period of time, the world experienced the end of bipolar regulation, an accelerated process of globalization, a general trend of de-territorialization of various political, economic, social and security issues, the development of means of transport and communication, an increased circulation of international finance, goods and persons. These are just some of the factors that greatly influenced the international system in general, as well as the security system in particular. In the new circumstances without the bipolar rivalry, the security settings have changed, so the security of sovereign states no longer represents only the protection of territories from external threats coming from other sovereign states, but it also includes the control of transnational threats coming from various non-state actors and the organized crime is one of them.

Today's threats in the security field come from more heterogeneous factors, ranging from changing of the global power structures, collapse of states and regional conflicts, the information technology revolution and national security, economic inequality and energy security, transnational organized crime and terrorism, health, diseases and biosafety, environmental safety etc. The organized crime has been present in society at almost all stages of its development, but new trends in the international system are being used by organized crime as well, manifesting itself in more perfidious forms of organization and spread, for the establishment of transnational criminal undertakings.

In the Western Balkans countries, the organized crime had a momentum of growth in this period, creating Balkan trafficking routes and turning the region into a bridge between criminal organizations. These organizations expanded their network to large parts of the globe making it impossible to combat with individual approaches from the states individually.

For trafficking of various narcotics from the countries of production to the market of Western and Central Europe are largely used the so-called Balkan routes, where according to the UN Office on Drugs report for the period 2009-2012, criminal organizations from the countries of the Western Balkans managed to benefit millions of dollars.

These illicit benefits now are another concern for the security of these countries, as these funds are laundered by these criminal organizations, where the proceeds from drug trafficking and other criminal activities enter the normal course of business and economic transactions.

This organized crime activity causes a negative chain effect establishing a parallel economy which affects the inflation 
process in the national economies, promoting corruption, criminal activities, financial and monetary speculation. The entry of illicit origin money into the legal financial system violates national security by producing corruption in politics and public administration, as well as the introduction of criminal activities into lawful business.

Referring to these data, it is evident that various organized crime organizations cooperate and have their own network with global reach, challenging the security at the state and international level. To successfully face the risks of organized crime, nowadays the individual states have increased their efforts on cooperation and interaction with various international actors, including other states, international organizations, intergovernmental cooperation etc.

Strategies and state security institutions are changing, creating cooperation and interaction opportunities in the fight against organized crime. Former methods and approaches of security institutions are being increasingly abandoned as a result of insufficiency to face this global phenomenon alone.

\section{References}

1. Berisha S. (2008). Globalizmi një proces $\mathrm{i}$ pashmangshëm (Globalization an inevitable process). University of Prishtina. (book). 92-104.

2. Collins A. (2014). Studime Bashkëkohore të Sigurisë (Contemporary security studies). UET/ PRESS, Tiranë. (book). 433-455.

3. Council of Europe/ European Commission (2006). Regional Project Carpo, Report on the situation of the Organized Crime and Economic Crime in the Southeast Europe, 11-20. Available at https://www.coe.int/t/dghl/cooperation/economiccri me/organisedcrime/projects/CARPO/Pctc 2006_20al b.pdf

4. Doninovska F. (2013). A look into the future, Challenges of regional cooperation on security in Western Balkans", European and security issues, quarterly magazine on security no. 25 , The institute of Democracy and Intermediation, Tirana. (Pdf, hand copy). 9-20.

5. European Commission (2005). Projekti Rajonal Carpo, Raporti mbi Gjendjen e Krimit te Organizuar dhe Krimit Ekonomik ne Evropën Juglindore (Regional Project CARPO, Report on the situation of the Organized Crime and Economic Crime in the Southeast Europe). Available at https://www.coe.int/t/dghl/cooperation/economiccri
me/organisedcrime/projects/CARPO/Pctc 2005 9\% 20Alb.pdf

6. European Commission (2007). Projekti Rajonal Carpo, Raporti mbi Gjendjen e Krimit te Organizuar dhe Krimit Ekonomik ne Evropën Juglindore (Regional Project CARPO, Report on the situation of the Organized Crime and Economic Crime in the Southeast Europe). Available at https://www.coe.int/t/dghl/cooperation/economic crime/corruption/Projects/CARPO/Pctc 2007 6_Alb .pdf

7. European Monitoring Centre for Drugs and Drug Addiction (2015). Drug use and its consequences in the Western Balkans, 10-11. Available at http://www.emcdda.europa.eu/edr2015

8. Fukuyama F. (2012). Origjina e rendit të ri politik (The origins of new political order). AISS Tiranë. (book). 485.

9. International Narcotics Control Board (2013). Report of the International Narcotics Control Board for 2013, Vienna International Centre. Available at https://www.incb.org/documents/Publications/Annua 1 Reports/AR2013/English/AR 2013 E.pdf

10. King G. \& Murray Ch. (2007). Rikonsiderimi i Sigurise Njerezore I. (Rethinking Human Security I). Security issues, quarterly magazine on security no.3, the Institution for democracy and intermediation Tirane. (Pdf, hand copy). 18-25.

11. Korajlic N., \& Muharremi D. (2009). Kriminalistika (Forensics). Rinvest Institut Prishtina. (Book). 396397.

12. Kuvendi i Republikes se Kosoves, 2008. Kushtetuta e Republikës se Kosovës (Assembly of the Republic of Kosovo, Constitution of the Republic of Kosovo).

13. http://www.kryeministriks.net/repository/docs/Kusht etuta.e. Republikes.se.Kosoves.pdf

14. Mingst A. K. (2008). Bazat e Marrëdhënieve Ndërkombëtare (Essentials of International Relations). AIIS, Tirana. (book). 340-344.

15. Paszkiewicz J. (2013). Bashkëpunimi Rajonal ne Ballkanin Perëndimor një Këndvështrim nga Brenda Bashkimit Evropian, Premisat dhe Pengesat (Regional Cooperation in Western Balkans, a review from within European Union, Premise and Obstacles). European security issues, quarterly magazine on security no. 25 , Institute of democracy and intermediation, Tiranë. (Pdf, hand copy). 107115.

16. Petroviq B., \& Dobovshek B. (2007). Rrjeti i krimit të organizuar (The network of organized crime). 
Faculty of Law, University of Sarajeva. (book). 27-

32.

17. PIETRO L. (2007). National Deputy Prosecutor of Anti-mafia. Mafiet e reja, Struktura dhe format e shfaqjes së krimit të organizuar transnacional analizë e përvojës gjyqësore italiane (New Mafia, the structure and form of appearing of organized transnational crime the analyses of Italian judicial experience. Training course for judges, prosecutors and judicial police officers, UNICRI Tirana. (Pdf). 57-96.

18. http://www.unicri.us/services/library_documentation/ publications/unicri_series/Manual_Albanian.pdf

19. Pirozzi N. (2013). Kuadri i bashkëpunimit evropian për menaxhimin e krizave të Post-Lisbonës (Adresimi i Sfidave te Reja te Sigurisë ne Shekullin e 21-të (European Union Framework for post-Lisbon Crisis Managgment: Addressing new security challenges in the 21 st century). European security issues, quarterly magazine on security, the Institution for democracy and intermediation, no. 26. (Pdf, hand copy). 27-32.

20. Sciacchitano G. (2007). Lufta kundër krimit të organizuar transnacional në hapësirën juridike dhe gjyqësore evropiane (The fight against transnational organized crime in the European legal and judicial area). Training course for judges, prosecutors and judicial police officers. UNICRI Tirana. (Pdf). 47-57.

21. http://www.unicri.us/services/library_documentation/ publications/unicri_series/Manual_Albanian.pdf

22. Suçeska M. (2006). Bazat e Kriminalitetit Ekonomik (Introduction to Economic criminality) FSK/S07/06, Prishtinë. (book). 37-45

23. United Nations office on drugs and crime (2006), World Drugs Report.

24. https://www.unodc.org/unodc/en/data-andanalysis/WDR-2006.html

25. United Nations office on drugs and crime (2005). Model legislation on money laundering and financing of terrorism. Available at https://www.unodc.org/documents/moneylaundering/ 2005\%20UNODC\%20and\%20IMF\%20Model\%20L egislation.pdf

26. United Nations Office on Drugs and Crime (2015). Drug Money the illicit proceeds of opiates trafficked on the Balkan route, 82. Available at https://www.unodc.org/documents/data-and$\underline{\text { analysis/Studies/IFF report } 2015 \text { final web.pdf }}$ 